\title{
Social conflicts between actors in marine resource management in Palabuhanratu, West Java, Indonesia
}

\section{Konflik sosial antaraktor dalam pengelolaan sumber daya kelautan di Palabuhanratu, Jawa Barat, Indonesia}

\author{
Eva Royandi \\ CIC Institute of Research and Social Consultants \\ Address: Jalan Sawo No. 12, RT. 3/RW. 7, Pondok Cina, Beji, Depok, West Java, \\ Indonesia 16424 \\ E-mail: evaroyandi1991@gmail.com
}

Article History: Received 27 June 2020; Accepted 18 October 2021; Published Online 01 December 2021

\begin{abstract}
Marine resources have become a niche of life for fishing groups on the coast of Palabuhanratu Sukabumi, West Java. The dependence of the fishing groups on natural resources has led to competition in the process of obtaining resources. The purpose of this study is to analyze stakeholders in marine resource management in Palabuhanratu. This research was conducted in Palabuhanratu, West Java, Indonesia. The research employed a qualitative approach with 60 informants, divided into 20 local fishermen, 20 migrant fishermen, and 20 external fishermen. The results of the study show several analyzes of the research objectives. First, several actors have an interest and influence in marine resource management in Palabuhanratu, including government actors, local fishermen, migrant fishermen, external fishermen, and marine tourism. Migrant fishermen have a high interest and influence in the process of exploiting marine resources in Palabuhanratu. Second, the relationships that exist between actors in the interaction process for the marine resource management in Palabuhanratu can take the form of negotiations and conflicts. Conflicts that occur are in the form of destroying other fishing gear, controlling the area, and protesting, while negotiations occur in the form of a cooperative relationship between groups of fishermen in catching fish and agreeing on boundaries for each type of fishing gear.
\end{abstract}

Keywords: actors; social conflicts; negotiations; marine resources management; Palabuhanratu

\begin{abstract}
Abstrak
Sumber daya laut telah menjadi relung kehidupan bagi kelompok nelayan di pesisir Palabuhanratu Sukabumi Jawa Barat. Adanya ketergantungan kelompok nelayan pada sumber daya alam telah memunculkan persaingan dalam proses memperoleh sumber daya. Tujuan penelitian ini adalah untuk menganalisis stakeholders dalam pengelolaan sumber daya laut di Palabuhanratu. Penelitian ini dilakukan di Palabuhanratu, Jawa Barat, Indonesia. Metode penelitian yang digunakan adalah pendekatan kualitatif dengan informan berjumlah 60 orang yang terbagi menjadi 20 nelayan lokal, 20 nelayan pendatang, dan 20 nelayan dari luar. Hasil penelitian menunjukkan beberapa analisis dari tujuan penelitian yaitu pertama, terdapat beberapa aktor yang memiliki kepentingan dan pengaruh dalam pengelolaan sumber daya laut Palabuhanratu, misalnya aktor pemerintah, aktor nelayan lokal, nelayan pendatang, nelayan dari luar, dan wisata bahari. Aktor nelayan pendatang memiliki kepentingan dan pengaruh yang tinggi dalam proses pemanfaatan sumber daya kelautan di Palabuhanratu. Kedua, hubungan yang terjalin di antara aktor dalam melakukan proses interaksi pengelolaan sumber daya laut Palabuhanratu dapat berbentuk negosiasi dan konflik. Konflik yang terjadi berupa saling merusak alat tangkap, menguasai wilayah dan protes, sedangkan negosiasi berupa hubungan kerja sama antarkelompok nelayan dalam menangkap ikan dan kesepakatan aturan batas wilayah untuk setiap jenis alat tangkap.
\end{abstract}

Kata kunci: aktor; konflik sosial; negosiasi; pengelolaan sumber daya kelautan; Palabuhanratu

\section{Introduction}

Marine resources with high economic value have the potential for conflict and exploitation, thus requiring good resource management to avoid damage and illegal fishing that will harm the state and society (Ciolek et al. 2018, Chapsos et al 2019, Gomez et al. 2021, Perez et al. 2021). We are aware 
that Indonesia has the potential of marine resources that can be utilized properly, thus requiring a comprehensive economic policy from the center to the coastal areas (Wekke \& Cahaya 2015, Chapsos \& Malcolm, 2017, Rochwulaningsih et al. 2019). Indonesia has a sustainable potential of marine resources or Maximum Sustainable Yield (MSY) of 7.3 million tons per year with allowable catches of 5.8 tons per year (BPS 2016). In addition, the potential of marine resources in Indonesia is supported by the presence of coastal villages or coastal areas of $15.61 \%$ of villages in Indonesia (BPS 2016). The challenge for coastal communities in managing marine resources is related to their own marine resources which have the risk of crisis and uncertainty due to fishermen's reliance on climate change occurring at sea when capturing marine resources (Mirajiani et al. 2014). Problems arising from uncertainty in the livelihoods of fishermen can be related to socio-economics as well as marginalization for small fishermen (Nissa et al. 2019). The choice for small fishermen is to work together or adapt to natural changes that occur in the sea (Subair et al. 2014). Adaptation, of course, is done with various stakeholders who have interests and influence in marine resource management. One form is by using knowledge about technology in the form of fishing gear that can be used (Husain 2011), such as bagan fishing gear used by all fishing groups in Palabuhanratu. Bagan is a fishing tool that floats in the sea for several days. Another form that can be applied (Quinn et al. 2010, Weigel et al. 2015) is carrying out the fishing process in marine resource areas that have not been utilized for economic purposes through policies issued by state authorities. However, the process is not easy because it involves various stakeholders including stakeholders among fishermen groups who have long carried out the management, utilization, and control of marine resources for economic purposes. Obie (2018) stated that economic interests can be the cause of damage to natural resources if there are no stakeholders with economic alignments who are concerned with environmental sustainability or natural resources.

The economy of the coastal community is still low because it is less able to seize opportunities in utilizing abundant coastal resources (Rukin 2018). In addition, the abundance of marine resources in Indonesia, of course, requires the management of resources together so that various social, economic, ecological, and political inequalities do not occur. As in Palabuhanratu, the potential for marine sustainability related to marine and fishery resources in the Nusantara Fisheries Port (PPN) of Palabuhanratu is quite high. With this potential of marine and fisheries, it is not surprising that the marine resources in Palabuhanratu become an arena of attraction for power between actors, including inter fishermen groups to control the sea resources of Palabuhanratu. Competition for space or sea area occurs because there is the potential of natural resources (sea) in Palabuhanratu that can provide benefits for interest groups. To understand the level of interest and influence of each actor in the management and utilization of marine resources in Palabuhanratu, a stakeholder analysis was conducted.

Stakeholders can be defined as parties (individuals, groups, or organizations) that are able to influence or can be influenced (receive impacts both positively and negatively) from various decisions (policies) taken (Friedman \& Miles 2006). Stakeholders as decision-makers recognize the need to understand who is affected by the decisions and actions they take, and who has the power to influence the results (Freeman \& Mcvea 2001, Read et al. 2009). Therefore, stakeholders are parties either individually, groups, and institutions (organizations) that can influence or be influenced in making a decision (policy) as well as the achievement of objectives in an activity or in the process of managing natural resources (marine resources).

Stakeholders include the community (who are affected or responsible for the distribution and control of decisions, including in the management and utilization of resources), researchers, government departments (responsible for the management of the area or as a policymaker), non-governmental organizations (NGOs), business and industry, and many other groups (Freeman \& Mcvea 2001, Friedman \& Miles 2006, Read 2015). Stakeholders can be defined as the process of involving stakeholders (actors) in decision making, management actions, and knowledge creation around the research area related to resource management (Friedman \& Miles 2006). Reed et al. (2009) stated that stakeholder participation is important in environmental management (marine resources). The reason is that the complex and dynamic nature of environmental problems requires flexible and transparent decision-making that 
includes a diversity of knowledge and values. Bryson (2004) explained that stakeholder analysis is an essential instrument in understanding the social context associated with program or project activities. Of course, it is related to the research field that the resource management program is important to be analyzed in relation to the process of managing marine resources by stakeholders.

Administratively, the marine resource management in Palabuhanratu is controlled by the state party represented by the Nusantara Fisheries Port (PPN) of Palabuhanratu which is legally opened directly by the President Soeharto in 1993. However, in fact, many fisherman actors, including local fishermen, migrant fishermen, and external fishermen only catch and carry out the buying and selling process in the sea area of Palabuhanratu. These groups of fishermen as actors can be positioned as controlling or maintaining access to marine resources. Therefore, the purpose of this study is to analyze stakeholders who have influence, interests, and relationships that are built in the management and utilization of marine resources in Palabuhanratu, West Java.

\section{Research Method}

The research was conducted at Sukabumi Seaport, Sukabumi Regency, West Java Province. The selection of the research location was based on several socio-economic considerations and the characteristics of marine and fisheries resources. The analysis unit of this research was a group of local fishermen, migrant fishermen, and external fishermen who utilize the marine resources of Palabuhanratu. The informants interviewed were groups of 60 fishermen and 20 people from the government managing marine resources.

The method used in this research was a qualitative approach using stakeholder analysis through several processes as follows: First, defining aspects of social and natural phenomena that are influenced by decisions or actions. Second, identification of individuals, groups, and organizations that are affected by or can influence part of the phenomenon (this may include non-human and non-living beings and future generations). Third, prioritizing these individuals and groups to be involved in the decision-making process (Reed et al. 2009). In addition, the methods for stakeholder analysis were carried out through three stages as follows: First, identifying stakeholders. Second, differentiating between and classifying stakeholders. Third, investigating the relationship between stakeholders (Reed et al. 2009). Stakeholder analysis can also be used to analyze actors or stakeholders who have the potential for conflict or are in conflict, not only in the form of cooperation (Friedman \& Miles 2006). Ribot \& Peluso (2003) stated that the process of power relations can be in the form of competition or conflictual relations to obtain natural resources or cooperation between various parties with an interest in the control, management, and utilization of marine resources. Therefore, stakeholder analysis is significant to do to find out the actors who have an interest and influence in marine resource management.

\section{Results and Discussion}

\section{Conflictual relations between interest groups in marine resource management in Palabuhanratu}

Actors appearing at the research site are those who directly benefit from marine and fisheries resources in the sea region of Palabuhanratu as well as those who indirectly benefit from marine resources. These actors with different interests include local fishermen, migrant fishermen, external fishermen, PLTU Managers, and Maritime Tourism. In addition, other actors have an interest in the management of marine resources in Palabuhanratu including the government, NGOs, traders, owners of capital, and the fishing industry, and fishing port or fisheries entrepreneurs.

Actors that were analyzed in detail related to their interests and influence were only groups of fishermen, including the groups of local fishermen, migrant fishermen, and external fishermen. The reason is that the hierarchical relationship between groups is not seen implicitly among these fishing groups. In addition, the fishermen groups are direct actors who have utilized marine resources from 1960 until now, 
although the actors' conditions in the historical development process of marine resource management in the Palabuhanratu area of Sukabumi have been different. However, as an initial stage, the identification of actors related to the actors mentioned by Bryant \& Bailey (1997) and Bryant (1998) is still being carried out, including non-fishermen who have interests and influence in managing and utilizing marine resources in the Palabuhanratu region, Sukabumi Regency, West Java Province.

First, the stakeholder is government. The government has an interest in taking part in utilizing the sea resources of Palabuhanratu. It is proven by the process of management by the government which began in the 1980s. However, officially, the management was started by the government through the PPN of Palabuhanratu in 1993. Therefore, the government has the power to issue policies related to all processes of management and utilization of marine resources in the Palabuhanratu region. Government decisions in the form of regulations (specify regulations) are a bundle of power held by the government, allowing it to manage and utilize the sea resources of Palabuhanratu. As a result, the government, both through the PPN of Palabuhanratu and the Department of Maritime Affairs and Fisheries, Sukabumi Regency has the right to regulate who can and may not use the marine resources in the Palabuhanratu region.

The role of the Sukabumi Regency Government through the Office of Maritime Affairs and Fisheries is to provide a variety of policies and development in the territory of the Nusantara Fisheries Port (PPN) of Palabuhanratu. Management by PPN of Palabuhanratu under the Department of Maritime Affairs and Fisheries of Sukabumi Regency and West Java Provincial Government, based on statutory regulations include First, law number 32 of 2014 concerning Maritime Affairs. Second, law number 31 of 2004 was later revised to law number 45 of 2009 concerning fisheries. Third, Regulation of the Minister of Maritime Affairs and Fisheries RI No. PER.02/MEN/2011 concerning fishing lanes and the placement of fishing gear and fishing aids in the territory of the Republic of Indonesia, and the minister's regulation regarding capture fisheries business. Fourth, Regional Regulation (Perda) of West Java Province number 7 of 2011 concerning fisheries management. Sixth, Sukabumi Regency Regional Regulation number 3 of 2014 concerning fisheries business permits. These rules formally regulate the management of natural resources including fisheries in the Palabuhanratu sea waters. The existence of these various arrangements is to manage the potential of natural resources in the sea waters of Palabuhanratu.

Second, the stakeholder is the fishermen groups of Palabuhanratu. Fishermen who take part in managing and utilizing marine and fisheries resources in the Palabuhanratu sea area are not only local people who come from the Palabuhanratu region of Sukabumi. Several other groups of fishermen also take advantage of marine resources and some have even settled in the coastal areas of Palabuhanratu. Herwening (2003) provides information from the results of his research that fishermen groups in Palabuhanratu in addition to the native population (ethnic Sundanese) there are also migrant residents who come from Bugis, Cirebon, Indramayu, Cilacap, Binuangen, and Jakarta. Bugis, Indramayu, and Cirebon fishermen are already domiciled in Palabuhanratu while Binuangen, Cilacap, and Jakarta fishermen are usually Andon (fishermen who carry out fishing activities outside their original fishing grounds, either permanently or only for a while, then return to their fishing grounds), only using Palabuhanratu as a fishing base and not settling in Palabuhanratu. The groups of fishermen, including local, migrant, and external fishermen have different interests in marine resources, making them vulnerable to the process of power relations in social relations, whether in the form of conflict or cooperation between actors who utilize marine resources in the coastal and marine areas of Palabuhanratu, Sukabumi Regency.

"I was an old-fashioned fisherman in the harbor for fishing, although I was still modest with a fishing rod. In the 1960s, there were even fishermen or fishermen's day parties, slaughtering buffaloes and distributing the meat to fishermen. Ah, I used to catch a lot of fish, not so much, it was difficult to catch fish far away" (Interview with ANA (chief), a local fisherman).

Before the arrival of newcomers and the participation of the government, local fishermen of Palabuhanratu were still catching fish in a simple manner and had not yet conducted large-scale fishing. Local fishermen have not been able to carry out the process of fishing to more distant areas due to the 
inadequate ability and fishing gear. They have a high interest in ecological and economic interests. Local fishermen consider marine sustainability to be very important to maintain because they believe that they should not only use but also participate in the utilization of marine resources. Around 1980, the government began to intervene and regulate activities related to the management and utilization of marine resources in the Palabuhanratu region of Sukabumi.

Palabuhanratu fisherman groups generally have scattered and integrated settlements with non-fisherman residents, but there are some areas inhabited by local fishermen, such as Cipateguran, Panyairan, and Cemara Villages. In addition, several fishermen who also use and manage marine resources in Palabuhanratu are scattered in the area of Sukabumi Regency. The interests of local fishermen are more ecological because they feel that marine resources are an important gift from God to be protected so as not to be damaged by unscrupulous elements in the management of marine resources. The next interest is to participate in utilizing marine resources. In fact, from the beginning, Palabuhanratu fishermen caught fish because of the arrival of migrant fishermen. This makes them brave and able to catch fish at a longer distance, not just catching fish using fishing gear at a close distance.

Third, the stakeholder is ethnic migrant fishermen (settled). Migrant fishermen have economic interests in managing and utilizing marine resources as evidenced by the ownership of fishing gear that is quite modern. Bugis fishermen are expected to come to Palabuhanratu after 1960 with a marked number of chart fishing gear utilized by them as well as by migrant fishermen who have learned the process of making charts to the operation of fishing gear charts. In addition, even local fishermen cannot be separated from migrant fishermen in the development of fishing activities in the sea area of Palabuhanratu of Sukabumi. Incoming fishermen have quite high economic interests, as evidenced by the mastery of more sophisticated fishing gear and supported with substantial capital.

\begin{abstract}
"I first went to Palabuhanratu via the Sea Line to Jakarta, then overland by vehicle to get to Palabuhanratu. I came here in 1960. I initially wanted to visit relatives in Sukabumi and play in the Palabuhanratu area. Some fishermen only fished around the coast of Palabuhanratu. Then, I lived temporarily in Palabuhanratu, but apparently, I was interested in developing a chart fishing gear in Palabuhanratu. Finally, I started it, making and operating in the 1970s. There finally many fishermen from South Sulawesi came here" (AMA, a Bugis ethnic migrant fisherman).
\end{abstract}

The results of the interview quotations with the migrant fisherman are quite clear that the migrant fisherman certainly has a very high economic interest in the control, management, and utilization of Palabuhanratu's marine resources. It is fair to assume that if one owner has ten ships and all of them are run by Bugis fishermen, thus there will be 50 Bugis fishermen for one skipper. Meanwhile, many owners come from the Bugis ethnic area. Although not all Bugis ethnicity owners hire all Bugis ethnicity fisherman, the majority of Bugis ethnicity owners do.

Not all migrant fishermen are ethnic Bugis; others are descended from Javanese fishermen. Fishermen from Java are spread in various fishing gears, including longlines and tuna fishing gears. However, as a result of the observations, it turns out that many fishermen from Java also have bagan like local fishermen who have used a lot of fishing gear in their fishing activities. Especially when the sea season is not friendly with fishermen, many of them use chart fishing gear in the sea area of Palabuhanratu because the bagan fishing gear can be stored at sea for several days, even up to one week.

\footnotetext{
"I've been here a long time because most of us catch shrimp and some make boats here. I didn't know that the already established Dramaga 1 area was a division between the Javanese and other fishermen. Most of the positions I occupied in Dramaga 1 were also occupied by people from Java, both from Cirebon and Cilacap. We also have internship tools or charts. But most fishermen from Cilacap also have and they use big ships like the longline." (USA, a Javanese migrant fisherman).
} 
Javanese migrant fishermen mastered the fishing net to catch shrimp and lobsters. They remain consistent in controlling, managing, and utilizing water resources related to the shrimp and lobster catchment areas although local fishermen join in fighting over the shrimp fishing areas together with Javanese fishermen. Therefore, conflictual relations cannot be avoided, either in the form of protests or the destruction of fishing gear. Furthermore, there are relations related to requests for division of territory to the PPN of Palabuhanratu and negotiating with local fishermen.

Fourth, the stakeholder is external fishermen (not settled). Banten fishermen, both Binuangen or outside Binuangen fishermen in the Banten region are adjacent to the Sukabumi Regency. Before 2000, Banten Province was part of West Java Province, so it is no wonder that Palabuhanratu fishermen and Banten fishermen always collaborate in the management and utilization of marine resources on the northern coast of Java. Even now, cooperation related to fish marketing is still ongoing, both by land and sea. Banten fishermen have quite high economic interests as evidenced by the existence of a special Purse Seinne fishing gear from Banten fishermen. When the fishing season is unsafe for Banten fishermen, they flock to the Palabuhanratu sea area to catch and disassemble fish and unload fish in the Palabuhanratu region. Local fishermen acknowledge the existence of Banten fishermen, albeit the number of ships entering the port region associated with the Seine Ship had begun to decrease at this time.

\section{Mapping of stakeholders in the Palabuhanratu fishing area}

Stakeholders have different interests and influences in managing marine resources. Of course, there are positive aspects and are in line with the objectives of management and utilization of marine resources. Others, however, are more negative and contradict existing objectives and norms for managing and utilizing marine resources. Reed et al. (2009) stated diverse interests and influences in managing marine resources from a variety of stakeholders so that it is necessary or important to make stakeholder mapping clearly. Stakeholder mapping will help managers with how to involve stakeholders in achieving goals or better management in managing and utilizing marine resources.

Table 1.

Levels of Interest and Influence of Stakeholders

\begin{tabular}{|c|c|c|c|c|c|}
\hline No. & Stakeholder category & Position & Interest & $\begin{array}{l}\text { Degree of } \\
\text { influence }\end{array}$ & $\begin{array}{l}\text { The degree } \\
\text { of interest }\end{array}$ \\
\hline 1 & Local Fishermen & Subjects & $\begin{array}{l}\text { Economy, social, } \\
\text { environment, and politics }\end{array}$ & Low & High \\
\hline 2 & $\begin{array}{l}\text { Javanese Ethnic } \\
\text { migrant Fishermen }\end{array}$ & Subjects & $\begin{array}{l}\text { Economy, social, } \\
\text { environment, and politics }\end{array}$ & Low & High \\
\hline 3 & $\begin{array}{l}\text { Buginese ethnic } \\
\text { migrant fishermen }\end{array}$ & $\begin{array}{l}\text { Key } \\
\text { Players }\end{array}$ & $\begin{array}{l}\text { Economy, social, } \\
\text { environment and politics }\end{array}$ & High & High \\
\hline 4 & $\begin{array}{l}\text { External Fishermen } \\
\text { (Banten Fishermen) }\end{array}$ & Subjects & Economy and social & Low & High \\
\hline 5 & $\begin{array}{l}\text { Nusantara Fisheries } \\
\text { Port (PPN) of } \\
\text { Palabuhanratu }\end{array}$ & $\begin{array}{l}\text { Context } \\
\text { Setters }\end{array}$ & Economy and environment & High & Low \\
\hline 6 & $\begin{array}{l}\text { Sukabumi Maritime } \\
\text { and Fisheries Service }\end{array}$ & $\begin{array}{l}\text { Context } \\
\text { Setters }\end{array}$ & $\begin{array}{l}\text { Economy, environment, and } \\
\text { politics }\end{array}$ & High & Low \\
\hline 7 & $\begin{array}{l}\text { Sukabumi Regency } \\
\text { Government }\end{array}$ & $\begin{array}{l}\text { Context } \\
\text { Setters }\end{array}$ & $\begin{array}{l}\text { Economy, social, } \\
\text { environment, and politics }\end{array}$ & High & Low \\
\hline
\end{tabular}

Mapping stakeholders, of course, is related to how to classify and categorize stakeholders. To analyze stakeholders, categorization analysis is used which classifies stakeholders according to their level of interests and influence (Bryson 2004, Reed et al. 2009). The method used to classify stakeholders is to use an interest influence matrix based on the interests and influences of stakeholders (Reed et al. 2009) on the policy of management of marine and fisheries resources in the PPN of Palabuhanratu. 
In-depth interviews with actors involved in the management and utilization of marine and fisheries resources in Palabuhanratu were conducted by identifying the level of interest and influence of actors on the management and utilization of marine resources of Palabuhanratu. The level of actors' interests can be seen from the use of resources. The higher the level of dependence of actors on marine resources in Palabuhanratu, the higher the interests. The higher the formal or informal power in the management and utilization of marine resources in Palabuhanratu, the higher the influence. The power here is also related to the authority possessed by the actors in the management and utilization of marine resources in Palabuhanratu. The influence and interests of these actors are listed in Table 1.

Based on the level of interest and influence possessed by stakeholders, stakeholders can be categorized into four types (Reed et al. 2009, Thomson 2015). Key players are stakeholders who have high interests and influence (power) on natural resources. Context setters are stakeholders who have a high influence (power) but have a low interest in natural resources. Subjects are stakeholders who have high interest, but a low influence (power) on natural resources. Meanwhile, the crowd is stakeholders who have low influence and interest in natural resources.

High

\begin{tabular}{|c|l|l}
\hline \multirow{2}{*}{ Low } & $\begin{array}{l}\text { Subjects: } \\
\text { Local Fishermen } \\
\text { Javanese ethnic fishermen } \\
\text { External Fishermen } \\
\text { (Banten fisherman) }\end{array}$ & $\begin{array}{l}\text { Key players: } \\
\text { Bugis ethnic migrant fishermen }\end{array}$ \\
\cline { 2 - 3 } & Crowd & $\begin{array}{l}\text { Context setters } \\
\text { Nusantara Fisheries Port (PPN) of Palabuhanratu } \\
\text { Sukabumi Maritime and Fisheries Service } \\
\text { Sukabumi Regency Government }\end{array}$ \\
\cline { 2 - 3 } & Power &
\end{tabular}

Figure 1.

Stakeholder mapping matrix based on interest and influence in the management of marine resources in Palabuhanratu, Sukabumi Regency

Source: Modification of Reed et al. (2009) and primary data

The position of the actor who occupies the position of the Subjects in Figure 1 is respected by local fishermen who have high interests because of the involvement of local fishermen in various types of fishing gear in the utilization of marine resources in Palabuhanratu. Local Fishermen join in using payang (fishing gear), and bagan (fishing gear) fishing tools in fishing, so their involvement is very large. They have a very high dependence on marine resources in Palabuhanratu. For local fishermen, marine resources are more than just a place to catch fish; they also hold a mystical meaning. This is evidenced by the strong tradition of thanksgiving of fishermen by sprinkling fish and turtle seeds into the middle of the sea or called Labuh Saji, by dropping fish seeds and hatchlings (turtles), with the hope that they get abundant catches and maintain good relations with Nyi Roro Kidul (the myth of the sea guard). Before the Sukabumi regency government was replaced in 2006, the tradition of fishermen in Palabuhanratu from generation to generation was throwing buffalo heads into the sea. The meat was then distributed to the fishing and non-fishing communities in Palabuhanratu. Palabuhanratu fishermen also believe in the existence of Ratu Laut Kidul, whose place is specifically in room 308 Samudra Beach Hotel near Palabuhanratu Beach. This belief also makes them unable to experience changes in fishing activities for a long time in the middle of the sea Palabuhanratu. 
Small or traditional fishermen are dependent on marine resources as a food system to meet their daily needs (Lowitt et al. 2020). The traditional behavior of the fishing community in Palabuhanratu is still very strong in carrying out fishing activities. Other than that, local fishermen have low influence in the decision-making process related to the management and utilization of marine resources. The low level of influence of local fishermen is due to the lack of their role in establishing relationships with the authorities related to the utilization of marine resources. In addition, the power held by local fishermen is not able to fight the power possessed by Bugis ethnic migrant fishermen who are more powerful, both power that is built legally and through structural and relational mechanisms in the form of technology, capital, markets, strong autonomy, social identity, knowledge, and patron-client to drive all fishermen in Palabuhanratu. Local fishermen are mostly only strengthened by the power of social identity as indigenous people who have traditionally utilized the Palabuhanratu sea area.

Key players are an actor who is able to adapt to the marine resource area of Palabuhanratu. Therefore, they can adapt to the existing socio-cultural and have expertise in the process of capturing marine resources, and can survive with changes in the coastal ecosystem in Palabuhanratu (Bakker et al. 2019, Haugen et al. 2021). Key players are occupied by Bugis migrant fishermen who have a great interest in marine resources. The dependence of Bugis migrant fishermen on the sea resources of Palabuhanratu is evidenced by their various strategies in obtaining resources. They came to the Palabuhanratu region as pioneers by sea through the sea of Jakarta and by land to get to the sea of Palabuhanratu. To be able to control marine resources, Bugis migrant ethnic fishermen use religious values and social approaches in approaching local fishermen to obtain resources. The high interest in the sea resources of Palabuhanratu is evidenced by the manufacture of bagan fishing gear (the local name is pagang). The making of pagang fishing gear was initiated by one of the Bugis ethnic fishermen who came to the Palabuhanratu region around the 1960s. Then, they spread in various fishing gear in Palabuhanratu. The superior fishing gear that is currently used is the FAD. The existence of fishing gear aids for Rumpon cannot be separated from the involvement of Bugis Fishermen who negotiate with the authorities and the authority of capital and social relations with fishing groups in Palabuhanratu in order to agree to hold a fishing gear for aump in Palabuhanratu. It is because this fishing gear will be able to master superior or economical fish species such as tuna and cakalang in the Palabuhanratu sea area. Apart from catching fish with bagan fishing gear, the benefits of fishing gear for FAD fishing for ethnic Bugis fishermen include the addition of new income. Currently, chart fishing gear can be owned by all groups of fishermen. Likewise, with fishing gear for FADs, the difference is that the majority of skippers and fishermen remain Bugis ethnic migrant fishermen. Even many of those who have boats and participate in cooperation with Bugis ethnic fishermen are Bugis migrant fishermen.

The ethnic Bugis migrant fishermen have a very strong influence because they have greater capital power compared to local fishermen. Power is established by ownership of capital and adequate fishing gear technology for fishing. The ethnic Bugis migrant fishermen provide a very large role when collaborating with the PPN of Palabuhanratu, resulting in the decision of the local authority to grant permits or policies on the use of fishing gear in the area of the Port of Palabuhanratu.

The formation of the socio-economic role of the fishing community occurs because of the socio-cultural influence of the interaction between local or indigenous fishermen and migrant fishermen (Lampe et al. 2020). Context Setters (the actors that have no direct interest in the fish catch) have three stakeholders including Palabuhanratu VAT, Sukabumi Regency Maritime Affairs and Fisheries, and Sukabumi Regency Government. PPN of Palabuhanratu serves as an institution that helps provide facilities related to the management and utilization of marine resources in Palabuhanratu. PPN of Palabuhanratu directly is under the authority of the Ministry of Marine and Fisheries of the Republic of Indonesia. PPN of Palabuhanratu also took part in checking related to fish production and distribution, especially the results of capture fisheries landed at PPN of Palabuhanratu. Although it does not have very high interest, the PPN of Palabuhanratu has a very high influence in the management and utilization of marine resources in Palabuhanratu. Because the PPN Palabuhanratu plays a role in determining whether a vessel is worth checking or not suitable for fishing, granting permits to fishermen, and giving an important role in the 
availability of facilities in the Palabuhanratu area. Control and supervision as well as power are of course legally done by the PPN of Palabuhanratu.

\section{Relationships among stakeholders}

To investigate the relationship among stakeholders, the actor linkages matrix method uses a matrix containing stakeholders in each column, as shown in Figure 1. Identification of relationships among stakeholders results in a relationship in the form of conflict and cooperation in the negotiation process (Reed et al 2009). Stakeholders analyzed in the relationship among various stakeholders include those whose position is as direct users to marine resources in PPN of Palabuhanratu, Sukabumi Regency. Analysis between local-level actors will be more interesting to see who are the actors with strong interests and influences so as to have an impact on the establishment of relations among actors that are conflictual and cooperative but remain in the realm of negotiations. Wegenast \& Schneider (2016) stated that abundance and lack of marine resources can influence the interests that lead to social conflicts.

The relationship between local fishermen and Bugis ethnic migrant fishermen has more conflictual relations. This is evidenced by the differences in fishing gear between the two. There is an open conflict relationship, although no violent conflict was found. However, conflicts carried out secretly occur such as complaints made by local fishermen to make the FAD aids that are widely used by ethnic Bugis fishermen can be reduced. The aids are considered to have made non-FAD fishermen aids experience a decrease in fisheries production. Relations between local and Javanese migrant fishermen occur in conflictual and cooperation (negotiations) relations. Conflictual relation occurs because the focus of Javanese migrant fishermen is more on catching shrimps so that some local fishermen who share the same sea area as Javanese ethnic migrant fishermen compete for space or fishing area This results in conflicts because local fishermen consider them more suitable to get the shrimp-rich territory, especially the area near the PLTU including the Cimandiri river estuary. The conflict can be seen from the interests of local fishermen related to obtaining catches and needs related to the preservation of fish resources (shrimp), while migrant fishermen are more focused on the need to obtain guarantees for business in the marine and fisheries areas of PPN of Palabuhanratu.

The relationship between local and external fishermen (Banten fishermen) is more about the relationship between Sundanese ethnic. Meanwhile, external fishermen who come from Jakarta and Cilacap are on large vessels that are not directly related to them. In addition, they operate in line 3 . The relationship of local and external fishermen (Banten fishermen) is more about cooperation (negotiation), especially in capturing and seizing fishing areas. In fact, local and Banten fishermen collaborate in fishing activities that are prohibited by the government.

The relationship between Bugis migrant and Javanese ethnic migrant fishermen is conflictual. Other than differences in fishing gear and fishing area, apparently, fishing gear has been confiscated over the territory because many Javanese fishermen also operate in pagang fishing gear (bagan). Although, they have conflictual relations, sometimes they collaborate in the negotiation process to resolve problems related to capture using the apparatus of fishing. Conflictual relations are strongly related to diverse groups of fishermen because each group of fishermen has different interests related to marine resources. This is proven by the differences and similarities of fishing gear and fishing areas among fishermen groups in the PPN of Palabuhanratu. The relationship of the external fishermen with ethnic Bugis migrant fishermen is more conflictual because the external fishermen are cooperating with local fishermen. In addition, the external fishermen have interests related to fishing areas located in the sea lane 1 of Palabuhanratu, both fishing through payang or net fishing gear. Meanwhile, Bugis ethnic migrant fishermen mostly use the tools of FADs and Traders (bagan). FADs are considered to have an impact on the catch due to the presence of fish FADs gathered in FADs. Likewise, with the pagang fishing gear used by the Bugis ethnic group, the tension in the conflict over the capture of the territory is higher. Even whoever first occupies the position of traders in the sea area may not be disturbed or shift the placement of the traders. 


\section{Conclusion}

Marine resources in Palabuhanratu have become part of life for the coastal communities of Palabuhanratu including for existing fishing groups. Fishermen groups have very high interest, but not all fishermen groups have high influence. Migrant fishermen have high interest and high influence because they have legal power relations with government actors. Local fishermen actors have high interest as local people, while external fishermen have an interest and influence because they are close to local fishermen. Conflictual relations between actors occur because they have an interest in Palabuhanratu's marine resources.

The conflict between local and migrant fishermen is related to FAD fishing gear which is mostly used by migrant fishermen. Apart from destroying fishing gear, there have also been protests against the government. The relationship between migrant and external fishermen is more about how external fishermen help local fishermen to control the area of FAD fishing gear. Negotiation between local and migrant fishermen is more about how they agree on fishing areas and comply with the rules that have been made. The government of the Palabuhanratu Resource Management has high interest and influence because they take a role as the party holding the policy as an intermediary from the central government.

\section{References}

BPS (2016) Statistik Sumber Daya Kelautan dan Pesisir. Jakarta: Badan Pusat Statistik.

Bakker YW, Koning J, \& Tatenhove J (2019) Resilience and social capital: The engagement of fisheries communities in marine spatial planning. Marine Policy 99:132-139. https://doi.org/10.1016/j. marpol.2018.09.032.

Bryant RL \& Bailey S (1997) Third World Political Ecology. London: Routledge.

Bryant RL(1998) Power, knowledge, and political ecology in the third world:Areview. Progress in Physical Geography: Earth and Environment 22 (1):79-94. https://doi.org/10.1177/030913339802200104.

Bryson JM (2004) What to do when stakeholders matter: Stakeholders identification and analysis techniques. Public Management Review 6 (1):21-53. https://doi.org/10.1080/14719030410001 675722.

Chapsos I, Koning J, \& Noortmann M (2019) Involving local fishing communities in policy making: Addressing illegal fishing in Indonesia. Marine Policy 109:1-9. https://doi.org/10.1016/j. marpol.2019.103708.

Chapsos I \& Malcolm JA (2017) Maritime security in Indonesia: Towards a comprehensive agenda? Marine Policy 76:178-184. https://doi.org/10.1016/j.marpol.2016.11.033.

Ciolek D, Matczak M, Piwowarczyk J, Rakowski M, \& Szefler K (2018) The perspective of polish fishermen on maritime spatial planning. Ocean \& Coastal Management 166 (1):113-124. https:// doi.org/10.1016/j.ocecoaman.2018.07.001.

Freeman RE \& Mcvea JF (2001) A Stakeholder Approach to Strategic Management. In: Hitt MA, Freeman RE, \& Harrison JS (ed). The Blackwell Handbook of Strategic Management. Oxford: Blackwell Publishing. 183-201. https://doi.org/10.1111/b.9780631218616.2006.00007.x.

Friedman AL \& Miles S (2006) Stakeholders: Theory and Practice. United Kingdom: Oxford University Press.

Gomez S, Carreno A, \& Lioret J (2021) Cultural heritage and environmental ethical values in governance models: Conflicts between recreational fisheries and other maritime activities in Mediterranean marine protected areas. Journal of Marine Policy 129:1-11. https://doi.org/10.1016/j. marpol.2021.104529.

Haugen IB, Cramer LA, Waldbusser GG, \& Conway FDL (2021) Resilience and adaptive capacity of Oregon's fishing community: Cumulative impacts of climate change and the graying of the fleet. Marine Policy 126:1-11. https://doi.org/10.1016/j.marpol.2021.104424.

Herwening E (2003) Modernisasi perikanan dan potensi konflik (studi kasus di Kelurahan Palabuhanratu, Kabupaten Sukabumi). Thesis, Institut Pertanian Bogor, Bogor. 
Husain F (2011) Sistem budaya masyarakat nelayan bahari Desa Lungkak Tanjung Luar, Lombok Timur, Nusa Tenggara Barat. Jurnal Komunitas 3 (1):40-50.

Lampe M, Waris L, \& Rajab M (2020) The influence of socio-economic gender's roles towards diabetes symptoms in South Sulawesi fishermen community. Journal of Enfermeria Clinica 30 (2):140143. https://doi.org/10.1016/j.enfcli.2019.07.065.

Lowitt K, Levkoe C, Spring A, Turlo C, \& Williams PL (2020) Empowering small-scale, communitybased fisheries through a food systems framework. Marine Policy 120:1-8. https://doi. org/10.1016/j.marpol.2020.104150.

Mirajiani, Wahyuni ES, Satria A, Saharuddin, \& Kusumastanto T (2014) Transformasi pranata patronase masyarakat nelayan: Dari ekonomi moralitas menuju ekonomi pasar. Jurnal Komunitas 6 (1):115134. https://doi.org/10.15294/komunitas.v6i1.2950.

Nissa ZNA, Dharmawan AH, \& Saharuddin (2019) Vulnerability analysis of small fishermen's household livelihoods in Tegal City. Komunitas: International Journal of Indonesian Society and Culture 11 (2):167-176. https://doi.org/10.15294/komunitas.v11i2.18583.

Obie M (2018) Exploitation of coastal and marine resources along Tomini Bay: Livelihood base versus concession rights. Masyarakat, Kebudayaan dan Politik 31 (1):36-45. http://dx.doi.org/10.20473/ mkp.V31I12018.36-45.

Perez EBE, Lozano LO, Rosales ODM, \& Tenorio AS (2021) Cultural importance of marine resources subject to fishing exploitation in coastal communities of Southwest Gulf of Mexico. Ocean \& Coastal Management 208:1-12. https://doi.org/10.1016/j.ocecoaman.2021.105605.

Quinn CH, Fraser EDG, Hubacek K, \& Reed MS (2010) Property rights in UK uplands and the implications for policy and management. Journal Ecological Economics 69 (6):1355-1363. http:// dx.doi.org/10.1016/j.ecolecon.2010.02.006.

Read MS (2015) Stakeholder mapping for the governance of biosecurity: A literature review. Journal of Integrative Environmental Sciences 2 (1):15-38. https://doi.org/10.1080/1943815X.2014.975723.

Reed MS, Graves A, Dandy N, \& Posthumus H (2009) Who's and Why? A typology of stakeholder analysis methods for natural resources management. Environmental Management 90 (5):19331949. https://doi.org/10.1016/j.jenvman.2009.01.001.

Ribot CJ \& Peluso NL (2003) A theory of access. Rural Sociology 68 (2)153-181. https://doi. org/10.1111/j.1549-0831.2003.tb00133.x.

Rochwulaningsih Y, Sulistiyono ST, Masruroh NN, \& Maulany N (2019) Marine policy basis of Indonesia as a maritime state: The importance of integrated economy. Marine Policy 108:1-8. https://doi.org/10.1016/j.marpol.2019.103602.

Rukin (2018) Economic development as a way to fight against poverty in a coastal society. Masyarakat, Kebudayaan dan Politik 31 (2):230-240. http://dx.doi.org/10.20473/mkp.V31I22018.230-240.

Subair, Kolopaking LM, Adiwibowo S, \& Pranowo MB (2014) Adaptasi perubahan iklim komunitas desa: Studi kasus di kawasan pesisir utara Pulau Ambon. Jurnal Komunitas 6 (1):57-69. https:// doi.org/10.15294/komunitas.v6i1.2943.

Thomson JR (2015) Tragedies of the Commons. In Thomson JR (ed). High Integrity Systems and Safety Management in Hazardous Industries. England: Oxford (UK). 281-292. https://doi.org/10.1016/ B978-0-12-801996-2.00017-9.

Wegenast T \& Schneider G (2016) Ownership matters: Natural resources property rights and social conflict in Sub-Saharan Africa. Political Geography 61:110-122. https://doi.org/10.1016/j. polgeo.2017.07.007.

Weigel JY, Morand P, Mawongwai T, Noel JF, \& Tokrishna R (2015) Assessing economic effects of a marine protected area on fishing household: A Thai case study. Fisheries Research 161:64-76. https://doi.org/10.1016/j.fishres.2014.06.012.

Wekke IS \& Cahaya A (2015) Fishermen poverty and survival strategy: Research on poor households in Bone Indonesia. Procedia Economics and Finance 26:7-11. https://doi.org/10.1016/S22125671(15)00962-4. 